\title{
The effect of the economic crisis on pay-performance link in South African state-owned enterprises
}

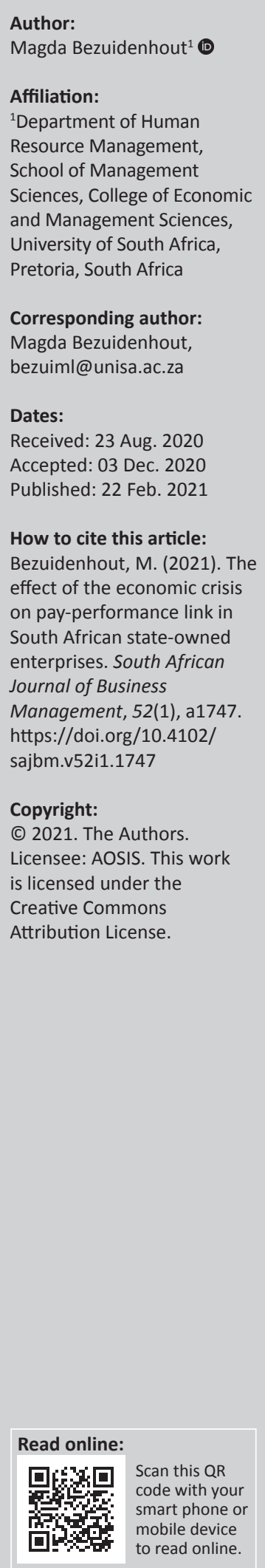

Purpose: The dissatisfaction with executive remuneration worldwide has increased because it is generally believed to have been instrumental to the 2008 Global Economic crisis. Central to this is the apparent unsatisfactory relationship between business performance and chief executive officer (CEO) remuneration. The primary aim of this study was to compare the payfor-performance association between CEOs' remuneration and state-owned entity performance before, during and after the economic crisis. It did so by assessing the chief executive remuneration link with state-owned enterprise performance from the period 2006 to 2014 .

Design/methodology/approach: Twenty-one schedule 2 state-owned enterprises in South Africa. This quantitative, longitudinal study, obtained secondary data from the annual reports of state-owned enterprises from the period 2006 to 2014. Ordinary least square multiple regression analysis was used as the principal statistical method.

Findings/results: The findings indicate that the link between chief executive remuneration and state-owned entity performance demonstrated different patterns in the pre- and post-crisis periods.

Practical implications: State-owned entity remuneration committees should place more emphasis on the financial efficiency measurements to enhance efficiencies in South African state-owned enterprises. Shareholders and regulators should take cognisance of measures to be used to assess the potential performance of state-owned entities, through executive remuneration, especially during an economic crisis. Findings could furthermore be of importance to other academics investigating this phenomenon.

Originality/value: This research provides additional knowledge to the limited research available on SOEs in South Africa. Further, it reveals that an economic downturn affects the link between CEOs' remuneration and SOE performance. This addresses a knowledge gap concerning the pay-for-performance link in South African SOEs and in emerging economies in general.

Keywords: executive remuneration; fixed pay; state-owned enterprises; total remuneration; South Africa.

\section{Introduction}

The dissatisfaction with executive remuneration escalated worldwide because of the perceived weak pay-performance link, especially after the 2008 Global Economic crisis (Modau, 2013). Researchers such as Bebchuk, Cohen and Holger (2010) and Shaw (2011) postulated that executive remuneration has widely been considered as being partly responsible for the economic crisis. This resulted in more attention being placed on executive remuneration from shareholders (Scholtz \& Smit, 2015). Even though the economic crisis improved during 2009 and 2010, the consequences of the collapse in the economy were nonetheless evident (Stoddard, 2020). There was a decline in the South African economic growth from $2.7 \%$ in 2012 to $1.8 \%$ in 2014. In addition, the economy decreased 0.6\% quarter-on-quarter in the first 3 months of 2014 (South African Reserve Bank, 2019).

Because the 2008/2009 economic crisis forced companies to reassess how their business operations were conducted, it is envisaged that, as part of this reassessment, the attitudes about determining executive remuneration changed as well to be more in line with company performance (Sonenshine, Larson, \& Cauvel, 2016). Furthermore, Yang, Dolar and Mo (2014) found that the link between business performance and chief executive officers' (CEOs) remuneration depicts different types of patterns in the pre- and post-crisis periods. Also, the economic crisis made structuring of remuneration practices more important than ever (Azim, Mei, \& Rahman, 2011) and it would be interesting to discover whether state-owned-enterprise (SOE) performance is reflected in CEOs' remuneration during the economic crisis. In addition, environmental factors, such as the economy, can influence executive remuneration paid by companies (Avallone, Quagli, \& Ramassa, 2014). Effective executive remuneration can lead to 
improved company performance and job creation, which is greatly needed in the economy (Steyn, 2015). The South African economy went into recession in 2008/2009 for the first time in 19 years and almost a million jobs were lost in 2009 alone, with the unemployment rate remaining high at 25\% (Rena \& Msoni, 2014). With increasing political pressure on government to review its economic policy, this adds to the reasons why South Africa is an interesting setting to study the issue at hand (Baxter, 2008).

This study focused on (and was limited to) schedule 2 South African SOEs such as Eskom, Transnet, South African Airways and Denel. These commercial SOEs are autonomous entities and wholly owned by the government to realise government's various socio-economic objectives (Accountant General South Africa, 2018) and are valuable drivers of development, specifically in developing economies (Mbo, 2017). These SOEs form an important part of fundamental industries that drive the South African economy by providing significant inputs that include electricity, transportation and telecommunications, thus contributing towards achieving the country's developmental objectives (Masekoameng \& Mpehle, 2018).

However, weak governance, maladministration, fraud and corruption claims and the lack of financial sustainability at a number of these SOEs have been in the public eye for the past few years (Accountant General South Africa, 2018). In addition, the exorbitant remuneration packages of CEOs of poor performing South African SOEs have been extensively publicised by the media and has attracted extensive interest from various stakeholders (Bezuidenhout, Bussin, \& Coetzee, 2018). The excessive remuneration levels of executives within South Africa SOEs have been studied because of the large wage gap between executives and lower-level employees and the perceived underperformance within SOEs (Bussin \& Ncube, 2017). In fact, the Public Review Commission Report for the period 2006-2010 showed that although a few SOE delivered significant returns, others, such as South African Forestry Companies (SAFCOL), South African Airways (SAA) Denel and Alexkor performed poorly and incurred losses the latter two SOEs incurred losses all 5 years (Kikeri, 2018).

Considering this, the overarching research question is what was the association between CEOs' remuneration and SOE performance pre-, during and post-economic crisis. The aim is, therefore, to compare the 2006 to 2010 (pre- and during the crisis) pay-for-performance (PFP) relationship with the PFP relationship post crisis (2011 to 2014).

The study contributes to the literature in two ways: Firstly, the study extends the existing literature regarding remuneration practices of SOEs (e.g. Ngwenya \& Khumalo, 2012; Reddy \& Wang, 2014). Secondly, most of the previous studies that examined the link between CEOs' remuneration and SOE performance employed data from the years before the economic crisis (e.g. Bussin \& Ncube, 2017; Modau, 2013). In addition, this study extends the literature by comparing the sensitivity of CEOs' remuneration to SOEs' performance between the pre- and post-crisis PFP relationship within a South African SOE environment. It further adds to the literature by assessing how the economic crisis altered the determinants of CEOs' remuneration within South African SOEs.

The article is organised as follows: The introduction section is followed by the literature review section. The next section discusses the methodology employed, followed by a section on the empirical findings. The last section discusses and concludes the research.

\section{Literature review}

Most of the literature reviewed has predominantly concentrated on the relationship between executive pay and business performance in listed companies, with a limited number of studies conducted on SOEs, especially from a South African perspective.

\section{State-owned enterprises versus private companies}

State-owned-enterprises and private companies seem to have different motivations and objectives. A private company, for this study, can be defined as a profit company, (1) that is not a public, personal liability or state-owned company and (2) its memorandum of incorporation prohibits it from offering any of its securities to the public and restricts the transferability of its securities. Stateowned-enterprises, in this study, are enterprises that are registered in terms of the Act as a company and listed as a public entity in schedule 2 of the Public Finance Management Act (PFMA), 1999 (PriceWaterhouseCoopers, 2012). The objectives of private sector companies can be clearly defined and measured according to profit and loss. The objectives of SOEs on the other hand are abstract, overarching and somewhat undefined and difficult to measure because the goals of SOEs apply to a broader jurisdiction than a single business, encompassing multiple programmes (GetSmarter, 2017; PriceWaterhouseCoopers, 2015). State-ownedenterprises have both commercial objectives and broader public policy objectives but balancing these goals can be difficult and lead to negative effects on efficiency and performance (Kikeri, 2018). This poses difficulties in evaluating the performance of the SOE and the CEO (Jensen, 2001), because it allows a weak performance in one perspective to be justified by the result achieved in others (Filho \& Alves, 2017).

Another difference between SOEs and private sector companies lies in their accountability. Chief executive officers in SOEs are accountable to a larger group of people (everyone in the governed area) and under constant public scrutiny (GetSmarter, 2017). These CEOs will eventually attempt to please as many people as possible whilst achieving results, adding to the complexity of their position. This can lead to erosion of the CEOs' accountability, causing 
negligence and corruption. In fact, one of the challenges identified by the Presidential Review Commission (PRC, 2012) was the lack of accountability within SOEs (Kikeri, 2018). Even though CEOs within private sector companies do not escape public scrutiny completely, they remain accountable to a small group of shareholders and employers. Their focus can, therefore, remain on maximising the bottomline (GetSmarter, 2017).

A further difference lies in the leadership of SOEs and private sector companies. Within SOEs, political pressures lead to frequent leadership changes, whilst in private organisations, individuals can stay in leadership positions for an unlimited number of years. Within SOEs, the choice of managers may be made on a political basis instead of merit (Filho \& Alves, 2018; Kanyane \& Sausi, 2015). This could explain why in the SOEs context, governance structures are convoluted with political cloud and unfair remuneration (Kanyane \& Sausi, 2015). Interestingly, Limbo (2019) postulated that good corporate governance ties in with effective leadership. Kikeri (2018) postulated that SOEs are run more like a government department instead of as efficient, autonomous and professionally run enterprises, and therefore face governance problems such as lack of an appropriate performance management system and disclosure practices to ensure transparency and accountability.

Even though CEOs' remuneration packages in SOEs and private companies are based on the same three components, namely salary, bonus and inter alia performance-based incentives, the stakeholder-orientated nature of SOEs makes it much more difficult to define and measure performance (Filho \& Alves, 2018). The reason for this is that SOEs in some instances are not run as a business, with the organisational culture of SOE mimicking that of the wider public sector. This makes it almost impossible to lift the organisational performance of most of the SOEs. In addition, SOE executives have generally little incentive to run the SOE under their control efficiently. As the state is often not concentrating on making a profit, governments would often bail out struggling SOEs, whereas in private sector, companies face the prospect of takeovers, and executives are fired if companies do not make a profit (Gumede, 2018). Another difference between SOEs compared with private companies is the difference in performance measures being used (Delves, 2016). The most common performance measure used by private companies is earnings before interest, tax, depreciation and amortisation (EBITDA) (Delves, 2018). Determining performance indicators and measuring the performance of SOEs by the executive authority responsible for a specific SOE is often ill-defined, unorganised and ambiguous (Khoza, 2009). This problem is further exacerbated by the fact that the capacity to monitor performance in SOEs is mostly lacking in the line ministry (PriceWaterhouseCoopers, 2011).

A general observation from previous studies show that different performance measures are used, with most being accounting and traditional performance measures, such as return on assets, return on equity (ROE) or revenue (Maloa \& Bussin, 2016). Nearly all the studies of SOEs used financial figures as a proxy for company performance to examine relationships between company performance and CEOs' remuneration, for example, Bezuidenhout et al. (2018), and Mbo and Adjasi (2014).

\section{Chief executive officers' remuneration amongst South African state-owned-enterprises}

Davies (2018) postulated that executive remuneration frameworks and practices are inconsistent amongst South African SOEs. For example, CEOs of entities of smaller size have vastly different basic salaries, whilst some smaller and less complex SOEs pay their executives relatively high salaries (PRC, 2013). This has a direct impact on the performance of SOEs, which is under constant public scrutiny, especially when these packages are disconnected from the company's performance. The PRC (2013) identified challenges regarding SOEs executive remuneration, which inter alia include:

- Differences across SOEs, as in most cases, their boards determine executive remuneration. This was supported by Kikeri (2018). The PRC further observed that there was no valid reason why some SOEs paid their executives much more than others. This could be because of a lack of clearly defined guidelines (Kikeri, 2018).

- The income disparity between executive management and workers on the lower level of the pay scale, which causes a widening wage gap.

- There is no centralised authority to manage SOE remuneration, which may result in executives determining their own packages. This could be linked to the managerial power theory, which argues that because of principal agent relationship, agents (executives) are in the natural position to use their discretion to set their own pay (Otten, 2007).

Whilst the poor performance of South African SOEs is widely publicised, many do not follow the remuneration guidelines issued by the Department of Public Enterprises (DPEs) that require remuneration to be benchmarked with the private sector (Maloa \& Bussin, 2016). This has led salary inequalities within SOEs, with the pay gap between executives and the average employee being just as big as within private companies. Data amongst the top 25 JSElisted companies showed that the average employees earned R589 850 per annum, and the average CEO R5.53 million per annum (StaffWriter, 2017a). Amongst nine prominent SOEs, the figures are very similar - average employee salaries were at R524 710 and the average CEO salary at R3.27m (StaffWriter, 2017b).

In addition, the excessive remuneration packages of CEOs in SOEs, is misaligned with the performance of SOEs in South Africa, as can be seen from the following cases: Denel's 2009/2010 annual report indicated that its CEO, Talib Sadik, was being paid R5.6m per annum. This despite Denel declaring a loss of R544m during 2009. Armscor's 2009/2010 annual report revealed that ex-CEO Sipho Thomo received 
an $\mathrm{R} 3.27 \mathrm{~m}$ remuneration packages (Panel to established to oversee SoE salaries, 2010), despite declaring a deficit of $\mathrm{R} 15.8 \mathrm{~m}$ (Armscor, 2009). The remuneration guidelines set by DPE have subsequently been revised in 2018, and whether SOEs will follow the new guidelines is yet to be seen.

Before the publication of the new SOE remuneration guide, it was the responsibility of each SOEs remuneration committee (RemCos) to develop remuneration policies and practices that realise the best value for stakeholders. This non-standardised approach led to certain individuals being offered better remuneration packages (Department of Public Enterprises, 2018, p. 5) as highlighted in the PRC (2013). The principles regarding CEO (executive director) payment are briefly outlined below (Department of Public Enterprises, 2018, p. 26):

- Remuneration may not surpass the market median of the recommended benchmark, without prior permission by the Shareholder Minister.

- Guaranteed remuneration will be paid based on a total cost to company approach.

- The overall annual increase percentages applied to guaranteed remuneration packages may not exceed the annual increase percentage negotiated with bargaining unit employees.

- Annual increases should solely be based on individual and relevant SOE performance.

- Individual and SOE performance below any agreed threshold should cancel out any annual increase to the CEO of a SOE.

\section{Empirical evidence on chief executive officers' remuneration and company performance}

Although numerous empirical studies have been conducted on CEOs' remuneration and company performance in both developed and developing economies, these results were mixed (Marimuthu \& Kwenda, 2019). Studies discussed in this section, all quantitative, archival studies, were undertaken mainly from private South African companies to research the relationship between CEOs' remuneration and business performance during the economic crisis (2008-2010). Most of the PFP studies in SOEs have been conducted in listed Chinese SOEs and these have in general been indecisive (Bussin \& Ncube, 2017).

Shaw (2011), whilst examining the association between CEOs' remuneration and business performance of financial services companies between 2005 and 2010, observed a moderate to a strong relationship between CEOs' remuneration and business performance. Shaw's results further revealed a diminishing relationship since 2008, emphasising the impact that macroeconomic trends (such as the economic crisis) have on the relationship of managerial power during periods of economic uncertainty. Scholtz and Smit (2015) examined the relationship between short-term executive remuneration and company performance (total assets, turnover and share price) for a sample of companies listed on the Alternative Exchange (AltX) in South Africa between 2002 and 2010. They found that the link holds during a period of economic crisis, except for share price, which was an insignificant performance indicator in the period. The authors postulate that the findings could be attributed to high standards of corporate governance. Van Blerck (2013), whilst studying businesses in the South African financial sector from 2002 to 2011, found a strong correlation amongst executive remuneration and economic value added (EVA), strengthening after the economic crisis, suggesting high standards of corporate governance in South African banks (Van Blerck, 2013).

Modau (2013), whilst studying 21 JSE Top 40 companies over 7 years (2006-2012), found that the relationship between CEOs' total remuneration and EVA tends to alter course, subject to the international economic condition. During an international economic downturn (e.g. the 2008 Global Economic crisis and August 2011 Stock Market Fall), it was discovered that the relationship between EVA and CEOs' total remuneration was positive. However, after the economic crisis, EVA was found to be negatively related to CEOs' total remuneration (Bussin \& Modau, 2015, p. 16). Azim, Mei and Rahman (2011), whilst conducting a study on the top 200 companies from the Australian Stock Exchange during 2007 to 2008 , found a positive and significant relationship between executives' remuneration and company performance during the economic crisis, with higher sensitivity to market-based performance measures than accounting-based performance measures. This result is, however, at odds with that of Vemala, Nguyen, Nguyen and Kommasani (2014). These authors determined that the economic crisis had a negligible but notable influence on CEOs' remuneration. They found that cash remuneration decreased significantly post-crisis, whilst equity-remuneration increased. This led to a declining relationship between CEOs' pay and business performance. Yang et al. (2014) whilst studying the relationship between CEOs' remuneration and business performance of US companies before and after the global economic crisis found that the relationship between $\mathrm{CEOs}^{\prime}$ remuneration and business performance demonstrates different patterns in the pre- and post-crisis periods.

Studies conducted on Chinese SOEs, and where a positive relationship was found between CEOs' remuneration and SOE performance are those of Mengistae and Xu (2004), Xin and Tan (2009), Chen, Ezzamel and Cai (2011), as well as Chen, Shen, Xin and Zhang (2012). Studies within South African SOEs are, however, limited. Otieno (2012), whilst studying 21 schedule 2 South African SOEs during 2007-2009, noted a positive relationship between executive remuneration and business performance. Bussin and Ncube (2017) investigated the relationship between CEOs' and CFOs' remunerations and performance amongst 21 schedule 2 South African SOEs for the period 2010-2014. These authors found a positive relationship between remuneration and performance using absolute profitability measures, such as earnings before interest and tax and depreciation and amortisation and net profit). Carlson and Bussin (2020), also whilst conducting a study within schedule 2 SOEs, 
observed a weak positive relationship between total pay with net profit or loss.

Ngwenya and Khumalo (2012) studied the relationship between CEOs' remuneration and financial performance amongst five South African SOEs that fall under the DPE and five that do not fall under DPE during the period 2009-2011. The authors found an insignificant relationship between remuneration and performance, which opposed the findings of most studies and statements that executive remuneration should be related to company performance for economic reasons. Marimuthu and Kwenda (2019) studied 33 commercial SOEs in South Africa that is listed under the Public Financial Management Act and found an inverse relationship between executive remuneration and financial performance. Bezuidenhout et al. (2016) found a weak negative relationship between fixed pay and profit and a weak negative relationship between total remuneration and net profit.

\section{Hypothesis development}

It could be expected that the PFMA, the Companies Act (Republic of South Africa, 2008) and King IV amongst others, would ensure increased regulation and monitoring of SOEs. These regulations and code will increasingly make it difficult for CEOs not to be remunerated according to performance as they give a clear indication that executive remuneration should align with company (SOE) performance (Carlson \& Bussin, 2020). Thus, the hypothesis is that there exists a positive association between $\mathrm{CEOs}^{\prime}$ remuneration and $\mathrm{SOE}$ performance pre-, during and post-economic crisis:

$\mathbf{H}_{\mathbf{1}}$ : There is a positive association between CEOs' fixed pay and SOE performance (measured through various financial measures) pre- and during the economic crisis (2006-2010).

$\mathbf{H}_{2}$ : There is a positive association between CEOs' total remuneration and SOE performance (measured through various financial measures) pre- and during the economic crisis (2006-2010).

$\mathbf{H}_{3}$ : There is a positive association between CEOs' fixed pay and SOE performance (measured through various financial measures) post-economic crisis (2011-2014).

$\mathbf{H}_{4}$ : There is a positive association between CEOs' total remuneration and SOE performance (measured through various financial measures) post-economic crisis (2011-2014).

\section{Methodology \\ Data and data sources}

The study was limited to South African schedule 2 SOEs. Owing to the small population, no sampling methodology was used. In this study, the entire population of 21 SOEs were included. To be included in the study, SOEs had to have 9 years of audited financial statements and 9 years' disclosed CEOs' remuneration data. Subsequently, 18 SOEs were included in the study. Secondary data were gathered from annual reports, which had been subjected to a financial audit of SOEs. Data collected was, therefore, regarded as accurate and credible.
TABLE 1: Summary of independent variables and measures.

\begin{tabular}{|c|c|}
\hline Variable & Measures \\
\hline Turnover (T) & $\begin{array}{l}\text { Turnover (or revenue) is the money received by a company } \\
\text { through typical business activities during a specified period } \\
\text { (Williams, Haka, Bettner, \& Carcello, 2006) }\end{array}$ \\
\hline $\begin{array}{l}\text { Operating } \\
\text { profit/loss (OP) }\end{array}$ & $\begin{array}{l}\text { Operating profit or loss is also known as gross profit or loss, } \\
\text { profit or loss before tax (Ward \& Price, 2017). For this study, } \\
\text { the unit of measurements for OP was as follows: OP = } \\
\text { operating income = gross profit = profit before tax }\end{array}$ \\
\hline $\begin{array}{l}\text { Net profit/loss } \\
\text { (NP) }\end{array}$ & $\begin{array}{l}\text { Net profit or loss - also labelled net income or profit or loss } \\
\text { after tax - is the absolute measure of accounting profit } \\
\text { (Graham \& Winfield, 2010). }\end{array}$ \\
\hline $\begin{array}{l}\text { Liquidity } \\
\text { ratio (LR) }\end{array}$ & $\begin{array}{l}\text { Liquidity refers to a company's ability to pay short-term } \\
\text { obligations with its current assets (Williams et al., 2006) }\end{array}$ \\
\hline $\begin{array}{l}\text { Solvency } \\
\text { ratio (SR) }\end{array}$ & $\begin{array}{l}\text { The solvency ratio, or debt ratio, considers the ratio between } \\
\text { the total assets and total liabilities of the company. This } \\
\text { indicates the proportion of the company assets that have been } \\
\text { financed by debt, with a higher value indicating higher risk } \\
\text { (Graham \& Winfield, 2010). }\end{array}$ \\
\hline $\begin{array}{l}\text { Return on capital } \\
\text { employed (ROCE) }\end{array}$ & $\begin{array}{l}\text { Return on capital employed measures the profitability and the } \\
\text { efficiency with which SOEs use their capital (European } \\
\text { Commission, 2016). The ratio can help to understand how well } \\
\text { a company is generating profits from its capital (Kenton, 2019). }\end{array}$ \\
\hline $\begin{array}{l}\text { Return on equity } \\
\text { (ROE) }\end{array}$ & $\begin{array}{l}\text { The ROE is often used to describe how well a company is } \\
\text { performing. This is because of its ratio of net profit or loss and } \\
\text { total equity invested by the shareholders (Graham \& Winfield, } \\
\text { 2010). }\end{array}$ \\
\hline $\begin{array}{l}\text { Irregular, fruitless } \\
\text { and wasteful } \\
\text { expenditure } \\
\text { (IFWE) }\end{array}$ & $\begin{array}{l}\text { Classified into three categories (South African Qualifications } \\
\text { Authority, 2013): } \\
\text { - Irregular expenditure, as defined by the Public Financial } \\
\text { Management Act (PFMA), means an expenditure, other than } \\
\text { unauthorised expenditure, that is, incurred in contravention of, } \\
\text { or not following, any applicable legislation (not just the PFMA). } \\
\text { - Unauthorised expenditure is the overspending on an approved } \\
\text { budget spending not in line with the original approved budget } \\
\text { item, or expenditure without the appropriate approval. } \\
\text { - Fruitless and wasteful expenditure, as defined in the PFMA, is } \\
\text { an expenditure that was made in vain and could have been } \\
\text { avoided had reasonable care been implemented. Such } \\
\text { expenditure may be of an operational or capital nature. }\end{array}$ \\
\hline
\end{tabular}

\section{Research design}

This empirical study followed an archival, ex post facto, longitudinal approach grounded on a descriptive quantitative research design. The study included the examination of secondary time series data for CEOs' remuneration and SOE performance measures in two periods, pre- and during the economic crisis (2006 to 2010) and post-economiccrisis (2011 to 2014).

This study used two components of CEOs' remuneration (the dependent variables): fixed pay and total remuneration (fixed pay and variable pay - short-term incentives only). Table 1 presents the independent variables for this study (based on most commonly used metrics in literature, except for the last two measures in the table). For this study, no control measures were used.

\section{Exclusions}

Long-term incentives (LTIs) were excluded from this study. State-owned-enterprises are not registered on the JSE, with a small number of SOEs providing LTI schemes (Bezuidenhout et al., 2018). Furthermore, the erratic nature of LTI pay-outs (Carlson \& Bussin, 2020; Kirsten \& Du Toit, 2018) would have introduced unsubstantiated influence during the research period.

\section{Statistical analysis}

Data were analysed by using SPSS (Version 22, for descriptive statistics) and EViews (Version 8). EViews accommodates 
panel data and provides the required econometric analysis needed for the type of data obtained. Polakow (2015) raised concerns regarding the use of standard statistical techniques in financial analysis that ignore autocorrelation and stationarity. Stationarity was addressed by conducting unit root tests and assessing autocorrelation through the DurbinWatson (DW). The author did not use an estimator, such as Heckmann's two-step correlation for selection bias, as it was (1) deemed unnecessary in the light of the repetitiveness of the sample and (2) assumes of bivariate normality and, therefore, require the use of probit, not logic (M. Pohl, personal communication, February 14, 2020). Potential bias has, therefore, been addressed.

The data set consisted of a panel of 162 observations (18 SOEs $\times 9$ years). Chief executive officers' remuneration and company performance components were tested for normality, stationarity (by Using the Augmented DickeyFuller [ADF] test) and autocorrelation (by using the DW test). Results of the assumption testing were considered in the analysis conducted by choosing the appropriate estimation method.

To ensure the variables used in the model were non-stationary, unit root tests were performed. Contradicting results were found for the various individual unit root tests. This could be because of the sample period (2006-2014) consisting of 9 years and 18 SEOs included in the sample. In an event of a short time (<12 years), stationarity testing may be a problem. Contradictory results from the various unit root tests are a typical outcome in the event of a short time (less than 12 years) with a fairly large number of observations (Kao, 1999). Thus, in cases where the periods are much smaller than the number of observations, stationarity is normally not considered. Furthermore, Kao (1999) also showed that estimates of the structural parameter binding two independent non-stationary variables converges to zero in the case of panel data, whereas in the case of time series it is a random variable, which indicates that although nonstationary panel data may lead to biased standard errors, the point estimations of the value of parameters are consistent.

Furthermore, the tolerance and variance inflation factor (VIF) information in the regression models were used to test for the presence of multicollinearity. Multicollinearity occurs when two explanatory variables are highly correlated $(r=0.90)$ (Westhoff, 2013). The presence of such high correlations indicates that variables do not hold any additional information needed in the analysis (Tabachnick \& Fidell, 2003). As a rule of thumb, if the VIF of a variable is greater than 10, multicollinearity is present. No multicollinearity problems were identified in the present research.

Inferential and multivariate statistics were carried out to permit the researcher to conclude the data. Also, Pearson's product-moment correlation tests were conducted to test the direction and strength of the relationship between the variables. Pooled ordinary least square (OLS) regression analysis was conducted, where it is presumed that the independent variables are strictly exogenous to the error terms of the model (Gujarati \& Porter, 2017). In addition, the multiple regression analyses used all the recorded independent variables into the equation simultaneously. Several regression models were run, until an optimal model, with the highest adjusted R-squared value and F-statistic value was attained. The resulting optimal solution can thus include statistical and non-statistically significant variable as the process is stopped when removing additional variables that will result in a reduction of adjusted R-squared over the previous regression model (Frost, 2019). This aims to achieve the set of independent variables that will explain the highest percentage of variance in the dependent variable. Thus, even if some of the measures are not statistically significant, they still add to a higher percentage of variance explained, thus warranting their inclusion.

\section{Empirical findings and analysis Descriptive statistics}

Table 2 presents the median and mean descriptive statistics of variables considered in this study for the years 2006 to 2010 and 2011 to 2014. Considering that there was an outlier in the CEOs' remuneration data, the median is reported on to filter out the values that are skewing the results (Orman, 2019). The researcher, therefore, reports on the medians. Along with Weiers (2010), as a rule, probable outliers do not affect medians.

Even though the researcher did not adjust the numbers for inflation, the descriptive statistics in Table 2 reveal that, whilst median CEOs' remuneration, turnover, IFWE and liquidity increased post-crisis (in nominal terms), the rest of

TABLE 2: Median and mean descriptive statistics of variables for the total data set.

\begin{tabular}{|c|c|c|c|c|}
\hline \multirow[t]{2}{*}{ Variable } & \multicolumn{2}{|c|}{ 2006-2010 } & \multicolumn{2}{|c|}{ 2011-2014 } \\
\hline & Mean & Median & Mean & Median \\
\hline CEOs' fixed pay & R2 462929.54 & R2 223425.50 & R3 363687.34 & R3 169000.00 \\
\hline CEOs' total remuneration & R4 171166.68 & R3 501078.00 & R4 936334.01 & R4 138150.00 \\
\hline Operating profit & R2 164328663.31 & R6 86573500.00 & R1 857234815.71 & R2 95352891.00 \\
\hline Net profit & R1 508857977.69 & R3 36196000.00 & R8 10453786.10 & R1 80465562.00 \\
\hline Turnover & R1 0214153509.52 & R3 418712500.00 & R1 6137354863.25 & R4 623119500.00 \\
\hline IFWE & R7 479124.08 & 0.00 & R1 6500284.25 & R1 17000.00 \\
\hline ROCE & 0.15 & 0.09 & 0.10 & 0.04 \\
\hline Return on equity & 0.10 & 0.09 & 0.10 & 0.05 \\
\hline Liquidity & 2.06 & 1.17 & 2.19 & 1.65 \\
\hline Solvency & 2.20 & 1.65 & 2.21 & 1.62 \\
\hline
\end{tabular}

CEO, chief executive officer; IFWE, irregular, fruitless and wasteful expenditure; ROCE, return on capital employed. 
the variables decreased significantly. Even though IFWE shows an increase, a possible explanation could be that none of the SOEs reported on IFWE before the economic crisis. The descriptive statistics reveal that SOEs were less profitable after the economic crisis than before the occurrence of the crisis, except for turnover, increasing with $26 \%$ (in nominal terms) after the economic crisis. It is furthermore noted that the CEOs' remuneration components increased post-crisis: fixed pay with $30 \%$ and total remuneration with $14 \%$.

The descriptive statistics further suggest that even though SOEs financial performance declined in the years after the economic crisis (except for turnover and liquidity), CEOs' remuneration increased. It is interesting to note that Carlson and Bussin (2020) in their study in the SOE environment, observed an average growth in total CEOs' pay of $28.68 \%$ over the period 2009 to 2016. This could suggest that South African SOEs did not have a good corporate governance practice in place regarding the level or structure of CEOs' remuneration. As expected, the descriptive statistics further reveal that SOEs were more profitable (as measured by operating profit) before the occurrence of the global economic crisis. From Table 2, it can be observed that SOEs liquidity increased after the economic crisis, from 1.17 to 1.65 . This means SOEs were in a better position to pay off all their short-term debt obligations during and after the economic crisis than before the crisis (2006-2010). Return on equity is significantly lower (at $5 \%$ and $9 \%$, respectively) in comparison to the findings of other studies, for example, $5.3 \%$ for the period 2013-2015 (Cheng, Li, \& Li, 2018).
Table 3 highlights the correlation between CEOs' remuneration components and SOE performance components for the period before and during the economic crisis (2006-2011), whilst Table 4 presents the correlation after the economic crisis (2011-2014).

The results of the Pearson Correlation analysis in Table 3 indicate a strong positive correlation between fixed pay and turnover $\left(r=0.607^{* *}\right)(p=0.05)$. However, a weak negative correlation between fixed pay and liquidity was found $\left(r=-0.213^{* *}\right)(p=0.044)$. Table 3 further indicates a strong to moderate correlation between total remuneration turnover $(r=0.572 * *)(p=0.05)$, operating profit $\left(r=0.502^{* *}\right)(p=0.05)$ and net profit $\left(r=-0.388^{*}\right)$ $(p=0.01)$.

The results of the Pearson Correlation analysis in Table 4 indicate a strong to moderate correlation between fixed pay operating profit $\left(r=0.441^{* *}\right)(p=0.05)$ and net profit $\left(r=0.276^{*}\right)(p=0.05)$, but a weak correlation with net profit. A similar result is evident for total remuneration. Considering that the agency theory advocates that an optimal contract is where CEOs' pay is linked with company performance (Jensen \& Meckling, 1976), the positive correlation between the CEOs' remuneration components and the financial performance components supports the theoretical predictions of the agency theory. Furthermore, according to the agency theory, performance should be linked to rewards (Padia \& Callaghan, 2020).

TABLE 3: Correlation between chief executive officers' remuneration and state-owned-enterprise performance: $2006-2010(N=90)$.

\begin{tabular}{|c|c|c|c|c|c|c|c|c|c|c|}
\hline Variables & Fixed pay & Total remuneration & Turnover & Operating profit & Net profit & Liquidity ratio & Solvency ratio & ROCE & ROE & IFWE \\
\hline Fixed pay & 1 & - & - & - & - & - & - & - & - & - \\
\hline Total remuneration & $0.772 * *$ & 1 & - & - & - & - & - & - & - & - \\
\hline Turnover & $0.607 * *$ & $0.572^{* *}$ & 1 & - & - & - & - & - & - & - \\
\hline Operating profit & 0.366 & $0.502 * *$ & $0.706 * *$ & 1 & - & - & - & - & - & - \\
\hline Net profit & 0.184 & $0.388^{*}$ & $0.426 * *$ & & 1 & - & - & - & - & - \\
\hline Liquidity ratio & $-0.213 * *$ & -0.128 & 0.154 & -0.098 & 0.022 & 1 & - & - & - & - \\
\hline ROCE & -0.198 & -0.156 & -0.031 & 0.130 & 0.086 & -0.031 & 0.080 & 1 & - & - \\
\hline ROE & -0.056 & 0.019 & 0.062 & $0.212 * *$ & $0.365 * *$ & -0.028 & 0.006 & 0.090 & 1 & - \\
\hline IFWE & 0.066 & -0.017 & 0.023 & -0.042 & -0.050 & -0.059 & -0.093 & 0.011 & -0.070 & 1 \\
\hline
\end{tabular}

CEO, chief executive officer; IFWE, irregular, fruitless and wasteful expenditure; ROCE, return on capital employed; ROE, return on equity.

*, Correlation significant at the 0.05 level (2-tailed); **, Correlation significant at the 0.01 level (2-tailed).

TABLE 4: Correlation between chief executive officers' remuneration and state-owned-enterprise performance: 2011-2014 ( $N=72$ ).

\begin{tabular}{|c|c|c|c|c|c|c|c|c|c|c|}
\hline Variables & Fixed pay & Total remuneration & Turnover & Operating profit & Net profit & Liquidity ratio & Solvency ratio & ROCE & ROE & IFWE \\
\hline Fixed pay & 1 & - & - & - & - & - & - & - & - & - \\
\hline Total remuneration & $0.852 * *$ & 1 & - & - & - & - & - & - & - & - \\
\hline Turnover & $0.639 * *$ & $0.517 * *$ & 1 & - & - & - & - & - & - & - \\
\hline Operating profit & $0.441 * *$ & $0.444^{* *}$ & $0.760 * *$ & 1 & - & - & - & - & - & - \\
\hline Net profit & $0.276^{*}$ & $0.297 *$ & $0.653^{* *}$ & $0.940 * *$ & 1 & - & - & - & - & - \\
\hline Liquidity ratio & -0.217 & -0.226 & -0.218 & -0.167 & -0.013 & 1 & - & - & - & - \\
\hline Solvency ratio & -0.163 & -0.023 & -0.161 & -0.077 & 0.055 & $0.678 * *$ & 1 & - & - & - \\
\hline ROCE & 0.056 & -0.085 & 0.036 & -0.052 & -0.067 & -0.087 & -0.070 & 1 & - & - \\
\hline ROE & -0.093 & -0.091 & -0.039 & 0.017 & 0.057 & -0.036 & -0.054 & -0.070 & 1 & - \\
\hline IFWE & -0.018 & 0.064 & 0.070 & 0.110 & 0.093 & -0.062 & -0.004 & -0.034 & -0.003 & 1 \\
\hline
\end{tabular}

CEO, chief executive officer; IFWE, irregular, fruitless and wasteful expenditure; ROCE, return on capital employed; ROE, return on equity.

*, Correlation significant at the 0.05 level (2-tailed); **, Correlation significant at the 0.01 level (2-tailed). 


\section{Key results}

The sections that follow detail the results of the correlation and regression analysis performed. It should be noted that inflation was not considered as research investigating the relationship between $\mathrm{CEOs}^{\prime}$ remuneration and company performance used nominal data and not constant data (e.g. Carlson \& Bussin, 2020).

Fixed pay: Fixed pay increased at a median average rate of $82 \%$ from $\mathrm{R} 1.67 \mathrm{~m}$ to $\mathrm{R} 3 \mathrm{~m}$ in total over 9 years (2006-2014), with a compound annual growth rate of $6.91 \%$. This comparison is relative to the South African inflation rate of $6.09 \%$ during 2014 (Statista, 2020). From the years 2006 to 2010 , fixed pay increased with $34 \%$, whilst increasing with $8 \%$ during the years 2011 to 2014 . This was contrary to the diminishing results in six of the eight measures of SOE performance in the same time frame. Figure 1 explains the median for fixed pay. Although inflation was not considered, it is apparent from the diagram that the mean and median fixed pay varied through the study period.

The highest increase in fixed pay, 23\%, was between 2006 and 2007. This finding reinforces Kuboya's (2014) view that the fixed proportion of executives' pay will, to a large extent, not decrease throughout times of unsatisfactory financial performance. Shaw (2011) postulated that it is unusual for fixed pay to weaken during an economic recession.

Total remuneration: Total remuneration increased with $93 \%$ over 9 years (2006-2014), with a compound annual growth rate of $7.58 \%$. This is higher compared with the South African inflation rate of $6.09 \%$ during 2014 (Statista, 2020). During the years 2006 to 2010 , median total remuneration increased with $70 \%$ and with $8 \%$ during the years 2011 to 2014 . A rising movement in the CEOs' total remuneration component was noted, peaking in 2009. Figure 2 illustrates the median total remuneration for the years 2006 to 2014 .
Noticeably, total remuneration varied throughout the period under study. At first glance, this tendency seems to reflect that of a few components of business performance.

\section{Regression analysis}

Ordinary least square multiple regression was performed to test the link between the CEOs' remuneration components (fixed pay and total remuneration) and components of SOE performance. In all the models, the panel data analysis was run with the dependent variables (fixed pay and total remuneration components) and the independent variables (SOE performance). The outcome of each regression model is shown in Table 5, Table 6, Table 7 and Table 8 (with the $t$-statistics in parentheses). The econometric model used in this research was as follows (Equation 1):

$$
\begin{aligned}
\text { CEO remuneration }_{t}= & \alpha+\beta_{1}(T)+\beta_{2}(\mathrm{OP})+\beta_{3}(N P)+\beta_{4}(L) \\
& +\beta_{5}(S)+\beta_{6}(R O C E)+\beta_{7}(R O E) \\
& +\beta_{8}(I F W E)+\varepsilon_{t}+A R(1)
\end{aligned}
$$

where:

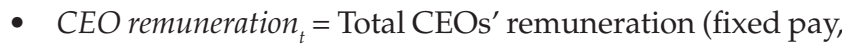
and total remuneration in rand denomination) paid to the CEOs of the sample SOEs in year $t$

- $\beta_{\mathrm{i}}=$ Respective coefficient

- $T=$ Turnover

- $N P=$ Net profit

- $O P=$ Operating profit

- $\quad L R=$ Liquidity ratio

- $S R=$ Solvency ratio

- ROCE = Return on capital employed

- $R O E=$ Return on equity

- IFWE = Irregular, fruitless and wasteful expenditure

- $t=$ the $t^{\text {th }}$ observation

- $\varepsilon=$ the error term

- $\mathrm{AR}(1)=$ Dependent variable at a lag of 1 (the term was introduced to address autocorrelation).

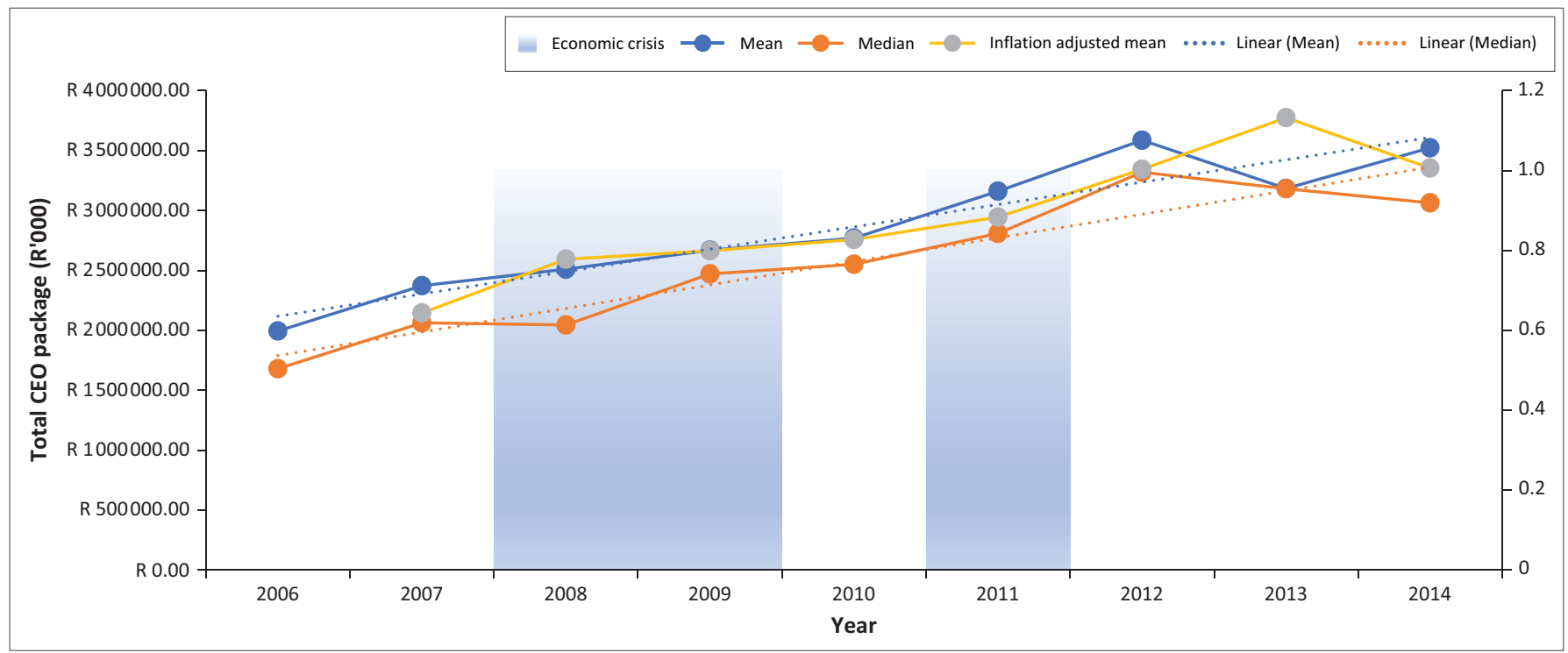

CEO, chief executive officer.

FIGURE 1: Median fixed pay. 


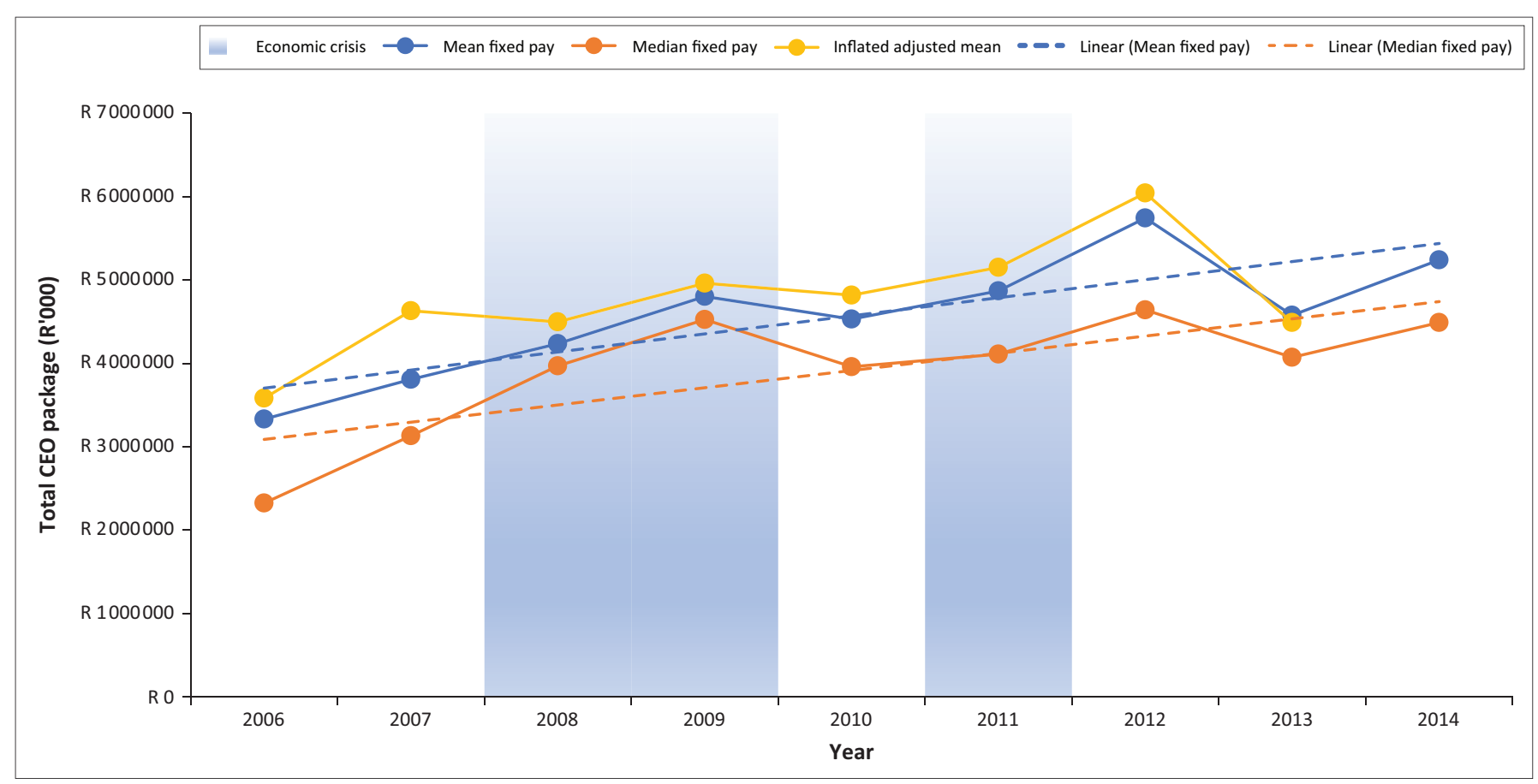

CEO, chief executive officer.

FIGURE 2: Median total remuneration.

Testing Hypothesis 1: The regression model was conducted on a panel of 18 cross-sectional units over 5 years. As there were no missing values, the panel was balanced. Using the histogram of data residuals, one outlier was identified and was subsequently omitted from the analysis. Table 5 presents a synopsis of the pooled regression analysis.

In the last regression model, Model 8 was considered as the optimal model, as the F-test statistic increased to 46.68 . The optimal model explained $57 \%$ (adjusted $R^{2}=0.57$ ) of the change in fixed pay. The findings in Table $5(p<0.00)$ proposes that turnover describes the change in the fixed pay component of CEOs' remuneration. Hypothesis 1 is supported because there is a positive relationship between fixed pay and turnover.

Testing of Hypothesis 2: The regression model was conducted on a panel of 18 cross-sectional units over 5 years. As there were no missing values, the panel was balanced. Table 6 presents the results of the pooled regression analysis.

Model 6 was considered the optimal model, as the F-statistic increased to 32.87. Model 6 shows that 58\% (adjusted $R^{2}=0.58$ ) of the difference in total remuneration was explained by operating profit and net profit. There is a strong positive relationship between total remuneration and operating profit (supporting $\mathrm{H}_{2}$ ), and a strong negative relationship between total remuneration and net profit $\left(\mathrm{H}_{2}\right.$ is, therefore, rejected). Both operating profit and net profit demonstrated a statistically significant relationship, although the relationship with net profit is an inverse relationship. The negative relationship with net profit is in contradiction with the agency theory, which posits that executive remuneration is positively linked to company performance (Jensen \& Murphy, 1990). This misalignment is an indication that a CEO has significant power to influence their remuneration packages, as they are remunerated despite the poor performance of SOEs (Marimuthu \& Kwenda, 2019).

Testing of Hypothesis 3: Table 7 presents a rundown of the regression analysis results of the link between fixed pay and SOE performance from the period 2011 to 2014. Because of the inclusion of the AR (1) term, the regression model comprised 70 balanced panel observations and 18 crosssectional units over the 4 years.

Because of the rise in the F-statistic to 30.06, accompanied by an increase of the adjusted $R^{2}$ value (0.69), Model 6 was regarded as the optimal model. Model 6 revealed that turnover, liquidity and IFWE explained $69 \%$ of the variance in fixed pay from the period 2011 to 2014 . It is possible to infer that turnover and liquidity ratio positively affected CEOs' fixed pay from 2011 to 2014, whilst IFWE negatively affected CEOs' fixed pay during the same period. Based on these results, $\mathrm{H}_{3}$ is both accepted and rejected.

Testing hypothesis 4: Table 8 presents the regression analysis results from the years 2011 to 2014 . The regression model was conducted on a panel of 18 cross-sectional units over 5 years. Because there were missing values, the panel was unbalanced.

Model 4 was considered as the optimal model, with an increase of the $F$-statistic to 24.13, together with an increase in the adjusted $R^{2}$ value (0.64). Model 4 revealed that ROCE, ROE and IFWE account for $64 \%$ of the variance in total remuneration for the years 2011 to 2014. It is possible to infer that ROCE and IFWE negatively affected CEOs' total 


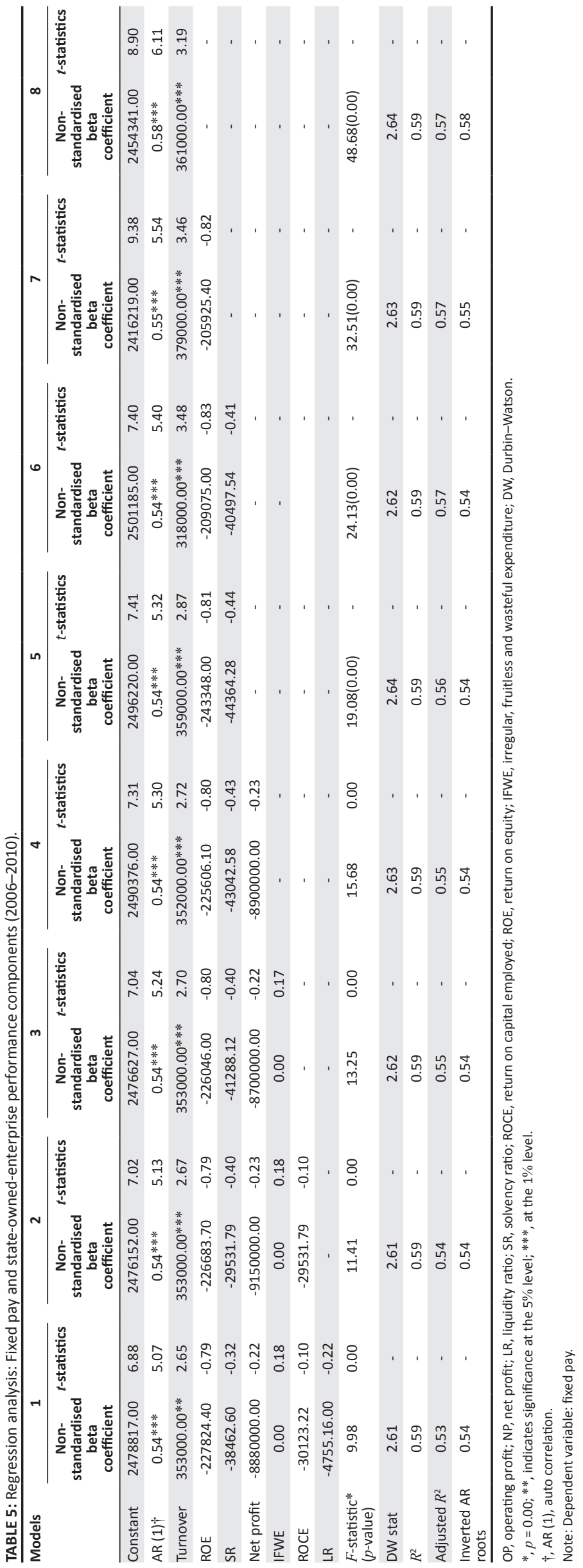



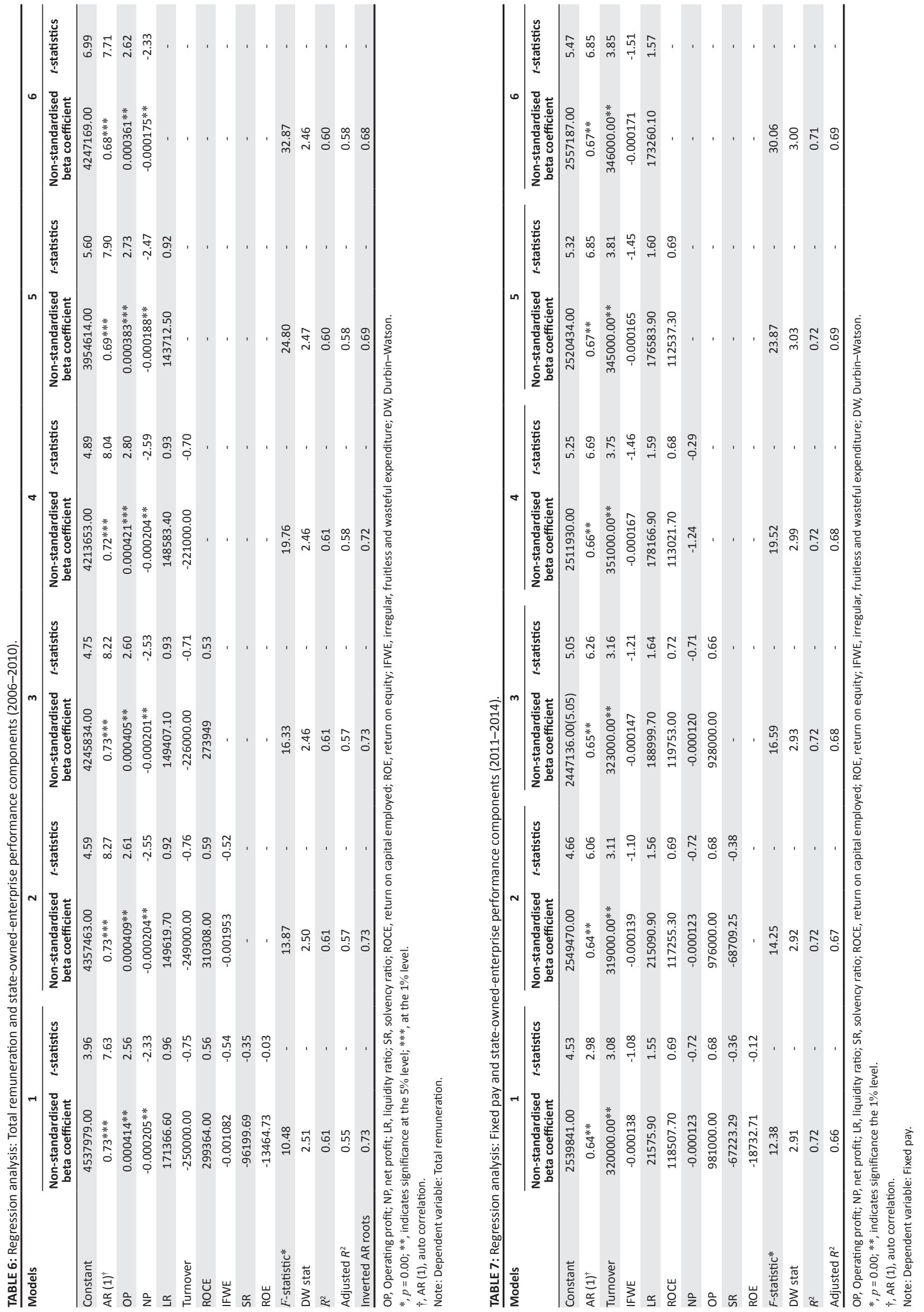
TABLE 8: Regression analysis: Total remuneration and state-owned-enterprise performance components (2011-2014).

\begin{tabular}{|c|c|c|c|c|c|c|c|c|}
\hline \multirow[t]{2}{*}{ Models } & \multicolumn{2}{|l|}{1} & \multicolumn{2}{|c|}{2} & \multicolumn{2}{|l|}{3} & \multicolumn{2}{|l|}{4} \\
\hline & $\begin{array}{c}\text { Non-standardised } \\
\text { beta coefficient }\end{array}$ & $t$-statistics & $\begin{array}{l}\text { Non-standardised } \\
\text { beta coefficient }\end{array}$ & $t$-statistics & $\begin{array}{c}\text { Non-standardised } \\
\text { beta coefficient }\end{array}$ & $t$-statistics & $\begin{array}{l}\text { Non-standardised } \\
\text { beta coefficient }\end{array}$ & $t$-statistics \\
\hline Constant & 5615339.00 & 3.45 & 5533097.00 & 3.57 & 5366363.00 & 3.82 & 6068994.00 & 5.60 \\
\hline ROCE & -625030.20 & -1.68 & -619048.30 & -1.69 & -614510.10 & -1.71 & -616921.10 & -1.74 \\
\hline ROE & 289099.10 & 0.94 & 323082.40 & 1.08 & 316546.90 & 1.07 & 333883.70 & 1.17 \\
\hline IFWE & -0.000426 & -1.66 & $-0.000449 *$ & -1.83 & $-0.000460 *$ & -1.93 & $-0.000478^{*}$ & -2.06 \\
\hline LR & 195518.40 & 0.67 & 180448.90 & 0.64 & 141505.10 & 0.59 & - & - \\
\hline SR & -152083.70 & -0.36 & -108479.40 & -0.26 & - & - & - & - \\
\hline OP & 490000.00 & 0.15 & - & - & - & - & - & - \\
\hline NP & 662000.00 & 0.02 & - & - & - & - & - & - \\
\hline F-statistic* & 9.97 & - & 13.21 & - & 15.71 & - & 24.13 & - \\
\hline DW stat & 3.39 & - & 3.38 & - & 3.34 & - & 3.41 & - \\
\hline$R^{2}$ & 0.68 & - & 0.67 & - & 0.67 & - & 0.67 & - \\
\hline
\end{tabular}

OP, Operating profit; NP, net profit; LR, liquidity ratio; SR, solvency ratio; ROCE, return on capital employed; ROE, return on equity; IFWE, irregular, fruitless and wasteful expenditure; DW, DurbinWatson.

$*, p=0.00 ; * *$, indicates significance at the $5 \%$ level.

$\dagger, A R(1)$, auto correlation.

Note: Dependent variable: Total compensation.

remuneration from 2010 to 2014 (rejecting $\mathrm{H}_{4}$ ), whilst ROE positively affected CEOs' total remuneration $\left(\mathrm{H}_{4}\right)$. Although IFWE displayed an inverse link, it was statistically significant $(p<0.10)$, proposing a stronger link than ROCE and ROE.

\section{Discussion}

With the worldwide dissatisfaction with executive remuneration that escalated during the global economic crisis, researchers postulate that executive remuneration has generally been considered as key in leading to the economic crisis. The purpose of the study was to compare the association between CEOs' remuneration and SOE performance during two different periods, namely 2006 to 2010 (pre- and during the economic crisis) and 2011 to 2014 (post-economic crisis). A possible explanation for the difference in results between fixed pay and total remuneration could be that fixed pay constitutes the fixed part of CEOs remuneration, regardless of performance. Total remuneration on the other hand, includes fixed pay and the value of any benefits received in addition to the salary and variable remuneration.

The findings of the negative relationship between the CEOs' remuneration components and some of the SOE performance measures do not support the economic theories of efficient remuneration (Kirsten \& Du Toit, 2018) or even the agency theory, whereby a positive relationship between business performance and executive remuneration is forecasted (Bezuidenhout et al., 2016). These results support the proposition that there is an agency problem in South African SOEs (Carlson \& Bussin, 2020).

Following the findings in this study, it seems that the link between the CEOs' remuneration components and SOE performance components demonstrated different patterns pre- and post-economic crisis. These findings are similar to findings of Yang et al. (2014). Turnover appeared to be the most stable variable in predicting fixed pay both during and post-economic crisis. The statistically strong positive link observed between fixed pay and turnover during the years 2006 to 2010 was contrary to expectations. A similar link was observed between total remuneration and operating profit. As a result of the poor performance of SOEs, the negative link between total remuneration and net profit was expected. This finding proposes that an increase in total remuneration was linked to a decrease in net profit. The descriptive statistics of net profit revealed that this measure declined by $89 \%$ between 2006 and 2010, whilst median total remuneration increased by $26 \%$ during the same period. As net profit is not one of the more conventional performance measures used in research in this topic, the conclusion is not as robust (Carlson \& Bussin, 2020).

Furthermore, results from the regression analysis of the post-crisis (2011 to 2014) date indicated that fixed pay had a positive relationship with turnover and liquidity ratio, respectively. Total remuneration had a negative relationship with ROCE and IFWE, respectively, and a positive relationship with ROE. This finding suggests that capital within SOEs is used less efficiently (European Commission, 2016). Interestingly, although IFWE displayed an inverse link with total remuneration, it was found to be statistically significant, proposing a stronger link than ROCE.

The results indicate the troubling effect of the economic downturn for SOEs in South Africa. The only component of SOE performance that did not decline during the study period was IFWE. Although it seems as if SOEs did not report on IFWE prior to 2011, this measure increased substantially from 2011 onwards. Interestingly, along with a draft audit report for the financial year ending 31 May 2014 by one of the leading auditing firms in South Africa, the South African Post Office (SAPO) spent R2.1 billion in IFWE 
during the 2013/2014 financial year; even though SAPO revealed an overdraft of $\mathrm{R} 250 \mathrm{~m}$ during the same period (BusinessTech, 2014).

The findings of this study are similar to prior results of, for example, Otieno (2012), and Carlson and Bussin (2020). Otieno detected a statistically strong correlation between CEOs' remuneration and net profit for 2007 and 2008. Carlson and Bussin (2020) reported a positive relationship between total pay and net profit. The finding of an inverse link between total remuneration and net profit is contrary to the findings of Vemala et al. (2014, p. 126). These authors postulate that irrespective of an economic crisis, business performance will have a positive link with CEOs' remuneration.

\section{Conclusion}

The findings from this study, firstly demonstrate that economic conditions will most likely affect the PFP relationship and secondly highlighted key performance measures that affect CEOs' remuneration in South African SOE before, during and after an economic crisis.

Even though the literature covering CEOs' remuneration is extensive and continues to evolve with the times, the literature regarding the link between remuneration after an economic shock is still in its embryonic phase, especially within an SOE environment. This study, therefore, contributes to the existing literature on executive PFP, especially within an SOE context given the fact that findings vis-à-vis the link between CEOs' remuneration and SOEs' performance stay unclear (Reddy \& Whang, 2014). This study has remuneration data at company level for 9 years. Such a data set enables us to complete a thorough factual investigation in analysing the inter-relationship of pay and performance amongst schedule 2 SOEs in South Africa.

Based on the findings, it is suggested that SOE boards need to design innovative remuneration contracts that incorporate the important role that turnover plays in the fixed pay component of CEOs' remuneration (especially during an economic crisis). The period of this study is unique because it encompasses a steady economic period before the economic crisis, a demanding and insecure period when the economic crisis occurred, followed by the fallout of the economic crisis. The results of the study indicate that an economic downturn affects the link between CEOs' remuneration and SOE performance. This addresses a knowledge gap concerning the PFP link in South African SOEs and in emerging economies in general. This knowledge could be useful to stakeholders who should evaluate trends regarding CEOs' remuneration (to appropriately assess their risks and benefits before approving remuneration at the annual meeting).

The first limitation is that the economic crisis was included in the study period - this could have given a biased representation of SOE performance in normal years. The second limitation is that the chosen remuneration and performance variables may not be the actual variables that will reveal the true relationship between them. There is a risk that the variables chosen are incorrect and, therefore, the study may not accurately report the real relationship between CEOs' remuneration and company performance. For example, turnover is normally used as a proxy for size, but in this study, turnover was used as a proxy for performance.

Findings in this study highlight key performance indicators that affect CEOs' remuneration in South African SOEs, which can be used by RemCos to determine the relationship between CEOs' remuneration and SOE performance, within an economic crisis, based on strong, statistically significant empirical research. Considering that South Africa is currently facing yet another economic crisis, this study is timely.

\section{Acknowledgements}

This article is based on a PhD study and the material in this article is similar to parts of the PhD study. This article should be seen as an extension of the PhD study.

\section{Competing interests}

The author declares that she has no financial or personal relationships that may have inappropriately influenced her in writing this research article.

\section{Author's contribution}

M.B. is the sole author of this research article.

\section{Ethical considerations}

This article followed all ethical standards for research without direct contact with human or animal subjects.

\section{Funding information}

This research received no specific grant from any funding agency in the public, commercial or not-for-profit sectors.

\section{Data availability}

Data sharing is not applicable to this article as no new data were created or analysed in this study.

\section{Disclaimer}

The views and opinions expressed in this article are those of the author and do not necessarily reflect the official policy or position of any affiliated agency of the author.

\section{References}

Accountant General South Africa. (2018). Status of state-owned enterprises: Genera report on the national and provincial audit outcomes for 2016-17. Retrieved from https://www.agsa.co.za/Portals/0/Reports/PFMA/201617/GR/04\%20status\%20 of $\% 20$ state-owned $\% 20$ enterprises.pdf.

Armscor. (2009). Annual report 2009/10. Retrieved from http://pmg-assets.s3website-eu-west-1.amazonaws.com/docs/101013armscorrep.pdf. 
Avallone, F., Quagli, A., \& Ramassa, P. (2014). The effects of accounting treatment and financial crisis on the stock option plans of Italian Companies. Economic and Business Review, 16(1), 77-95. Retrieved from http://ojs.ebrjournal.net/ojs/ Business Review, 16(1), 77-95. Retrieve
index.php/ebr/article/view/333/pdf_2.

Azim, M.I., Mei, J.C., \& Rhaman, S. (2011). Executive's remuneration and company performance: An evaluation. Corporate Board: Role, Duties \& Composition 7(2),16-31. https://virtusinterpress.org/IMG/pdf/10-22495_cbv7i2art2.pdf.

Baxter, R. (2008). The global economic crisis and its impact on South Africa and the country's mining industry, paper presented at the South African Reserve Bank Conference series on Challenges for Monetary Policy-makers in Emerging Markets,
Bela-Bela, South Africa, October. Retrieved from https://www.resbank.co.za/ Lists/News\%20and\%20Publications/Attachments/51/Roger+Baxter.pdf.

Bebchuk, L.A, Cohen, A., \& Holger, S. (2010). The wages of failure: Executive remuneration at Bear Stearns and Lehman 2000-2008. Yale Journal on Regulation, 27, 257-282. Harvard Law and Economics Discussion Paper No 657, ECGI - Finance Working Paper No 287. Retrieved from https://ssrn.com/abstract=151352.

Bezuidenhout, M.L. (2016). The relationship between CEO remuneration and company performance in South African state-owned entities. Doctoral thesis. Pretoria: University of South Africa.

Bezuidenhout, M.L., Bussin, M.H.R, \& Coetzee, M. (2018). The chief executive officer pay-performance relationship within South African state-owned entities. South
African Journal of Human Resource Management, 16(0), a983. https://doi. African Journal of Human Resou
org/10.4102/sajhrm.v16i0.983.

Bussin, M., \& Modau, M.F. (2015). The relationship between chief executive officer remuneration and financial performance in South Africa between 2006 and 2012 SA Journal of Human Resource Management, 13(1), 6-16. https://doi. SA Journal of Human Reso
org/10.4102/sajhrm.v13i1.668

Bussin, M.H.R., \& Ncube, M. (2017). Chief executive officer and chief financial officer compensation relationship to company performance in state-owned entities.
South African Journal of Economic and Management Sciences, 20(1), 1-18. https://doi.org/10.4102/sajems.v20i1.1644

BusinessTech. (2014). SA Post office fingered for R2.1 billion irregular expenditure Retrieved from http://businesstech.co.za/news/government/67578/sa-postoffice-fingered-for-r2-billion/.

Carlson, C., \& Bussin, M.H.R. (2020). Relationship between executive pay and company financial performance in South African state-owned entities. South African Journal of Human Resource Management, 18(6), a1211. https://doi. org/10.4102/sajhrm.v18i0.1211

Chen, J., Ezzamel, M., \& Cai, Z. (2011). Managerial power theory, tournament theory and executive pay and in China. Journal of Corporate Finance, 17(4), 1176-1199. https://doi.org/10.1016/j.jcorpfin.2011.04.008

Chen, D., Shen, Y., Xin, F., \& Zhang, T. (2012). Overemployment, executive pay-forperformance sensitivity and economic consequences: Evidence from China. Chin Journal of Accounting Research, 5, 1-16. https://doi.org/10.1016/j.cjar.2012.03.001

Cheng, H., Li, H., \& Li, T. (2018). The performance of state-owned enterprises: New evidence from the China employer-employee survey. In Stanford Center on Global Poverty and Development (pp. 1-44). Retrieved from https://kingcenter.stanford. edu/sites/default/files/publications/1037wp.pdf

Davies, T. (2018). Chief executives' pay is no small issue. Retrieved from https://mg co.za/article/2018-12-14-00-chief-executives-pay-is-no-small-issue.

Delves, D. (2016, March 06). Insights. Willis Towers Watson. Retrieved from https://www. towerswatson.com/en/Insights/Newsletters/Global/executive-pay matters/2018/03/Private-public-co-exec-comp-practices-where-they-merge-diverge.

Delves, D. (2018, March 06). Private and public company executive compensation practices: Where they merge and diverge. Willis Towers Watson. Retrieved from https://www.willistowerswatson.com/en-CA/Insights/2018/03/Private-public-coexec-comp-practices-where-they-merge-diverge.

Department of Public Enterprises. (2018). Remuneration booklet. The guide for State Owned Companies. Remuneration and Incentives for executive directors, Owned Companies. Remuneration and Incentiv
prescribed officers and non-executive directors.

European Commission. (2016). State-owned enterprises in the EU: Lessons learns and ways forward in a post-crisis context. Institutional Paper 031. Retrieved from https://ec.europa.eu/info/sites/info/files/file_import/ip031_en_2.pdf.

Filho, J.R.F., \& Alves, C.F. (2018). Mecanismos de controle na governança corporativa das empresas estatais: uma comparação entre Brasil e Portugal. Cadernos EBAPE.BR, 16(1), 2-13. https://doi.org/10.1590/1679-395172454

Frost, J. (2019). Regression analysis. An intuitive guide for using and interpreting linea models [ebook]. Retrieved from Statistics by Jim website: https://statisticsbyjim. selz.com/item/regression-analysis-an-intuitive-guide.

GetSmarter. (2017). The difference between public and private sector management. Retrieved from https://www.getsmarter.com/blog/career-advice/public-andprivate-management/.

Graham, M., \& Winfield, J. (2010). Understanding financial statements. Cape Town: Cape Business Seminars.

Gujarati, D.N., \& Porter, D.C. (2017). Basic econometrics (6th ed.). New York, NY: McGraw Hill/Irwin.

Gumede, W. (2018, December 3). Policy Brief 30: Positioning Africa's SOEs to deliver on the developmental mandate. Democracy Works Foundation. Retrieved from https://democracyworks.org.za/policy-brief-30-positioning-africas-soes-todeliver-on-the-developmental-mandate/.

Jensen, M.C. (2001). Value maximization, stakeholder theory, and the corporate objective function. Journal of Applied Corporate Finance, 14(3), 8-21. https://doi. org/10.1111/j.1745-6622.2001.tb00434.x

Jensen, M.C., \& Meckling, W.H. (1976, July 1). Theory of the firm: Managerial behavior agency costs and ownership structure. Papers.Ssrn.Com. Retrieved from https:// papers.ssrn.com/abstract $=94043$.
Jensen, M.C., \& Murphy, K.J. (1990). Performance pay and top-management incentives. The Journal of Political Economy, 98(2), 225-264. https://doi.org/ 10.1086/261677

Kanyane, M.H., \& Sausi, K. (2015). Reviewing state-owned entities' governance landscape in South Africa. African Journal of Business Ethics, 9(1), 28-41. https:// doi.org/10.15249/9-1-81

Kao, C. (1999). Spurious regression and residual-based tests for cointegration in panel data. Journal of Econometrics, 90(1), 1-44. https://doi.org/10.1016/s03044076(98)00023-2

Kikeri, S. (2018). Corporate governance in South African state-owned enterprises. Washington, DC: World Bank. https://doi.org./10.1596.30029

Kenton, W. (2019). Understanding return on capital employed. Retrieved from https:// www.investopedia.com/terms/r/roce.asp.

Khoza, S. (2009). Board independence within SOEs. The premier conference on corporate governance, Sandton. Retrieved from https://slideplayer.com/ corporate gover
slide/4077523/.

Kirsten, E., \& Du Toit, E. (2018). The relationship between remuneration and financial performance for companies listed on the Johannesburg stock exchange. South African Journal of Economic and Management Sciences, 21(1), 10 pages. https:// doi.org/10.4102/sajems.v21i1.2004

Kuboya, D. (2014). A critical analysis of executive remuneration and business performance for South African listed companies. Master's dissertation. Stellenbosch: University of Stellenbosch.

Limbo, C.M. (2019). An analysis of the performance of state-owned enterprises in Namibia: Case studies in the transport section. PhD thesis. Stellenbosch University of Stellenbosch.

Maloa, F., \& Bussin, M. (2016). Determinants of executive compensation in South African state-owned enterprises. South African Journal of Labour Relations, 40(1) 8-24. https://doi.org/10.25159/2520-3223/5857

Marimuthu, F., \& Kwenda, F. (2019). The relationship between executive remuneration and financial performance in South African state-owned entities. Academy of Accounting and Financial Studies Journal, 23(4), 1-18. Retrieved from https://www. abacademies.org/articles/The-Relationship-between-Executive-Remunerationand-Financial-Performance-in-South-African-1528-2635-23-4-445.pdf.

Masekoameng, R., \& Mpehle, Z. (2018). Financial sustainability of South African stateowned enterprises: A case of Limpopo Economic Development Agency. London Journal of Research in Humanities and Social Sciences, 18(3), 21-32. Retrieved from https://journalspress.com/LJRHSS_Volume18/404_Financial-Sustainabilityof-South-African-State-Owned-Enterprises-A-Case-of-Limpopo-EconomicDevelopment-Agency.pdf.

Mengistae, T., \& Xu, L.C. (2004). Agency theory and executive compensation: The case of Chinese state-owned enterprises, Journal of Labor Economics, 22(3), 615-637. https://doi.org/10.1086/383109

Mbo, M. (2017). Drivers of organisational performance: A state-owned enterprise perspective. Stellenbosch: Stellenbosch University.

Mbo, M., \& Adjasi, M.J. (2014). Drivers of organisational performance: A state-owned enterprise's perspective. The Biennial Convergence of the Economic Society of South Africa. Bloemfontein: University of the Free State.

Modau, M. (2013). The relationship between chief executive officer (CEO) remuneration and financial performance of an organization. MBA dissertation. Pretoria: University of Pretoria, Gordon Institute of Business Science. Retrieved from https://repository.
up.ac.za/bitstream/handle/2263/40578/Modau_Relationship_2013.pdf; sequence $=1$.

Ngwenya, S., \& Khumal, M. (2012). CEO compensation and performance of State Owned Enterprises in South Africa. Corporate Ownership and Control, 10(1). https://doi.rg/10.22495/cocv1oi1art9

Orman, E. (2019). Using average or median aggregators. Zendesk. Retrieved from https://support.zendesk.com/hc/en-us/articles/228989407-Using-average-ormedian-aggregators.

Otieno, D. (2012). The relationship between financial performance and executive remuneration in South African state-owned enterprises: An agency theory perspective. MCom minor dissertation. Johannesburg: University of Johannesburg.

Otten, J. (2007). Theories on executive pay. A literature overview and critical assessment. Retrieved from https://papers.ssrn.com/sol3/papers.cfm?abstract id $=1088272$.

Padia, N., \& Callaghan, C.W. (2020). Executive director remuneration and company performance: panel evidence from South Africa for the years following King III. Personnel Review. https://doi.org/10.1108/PR-08-2019-0429

Polakow, D. (2010). If a portfolio manager who cannot count finds a four-leaf clover, is he still lucky? Investment Analysts Journal, 39(72), 53-71. https://doi.org/10.108 0/10293523.2010.11082523

Presidential Review Committee. (2012). Report on the Presidential Review Committee (PRC) of state-owned entities. Retrieved from https://www.gov.za/documents/ report-presidential-review-committee-prc-state-owned-entities-soes.

PriceWaterhouseCoopers. (2011). State-owned enterprises: Governance responsibility and accountability Public Sector Working Group: Position Paper 3. PriceWaterhouse Coopers. Retrieved from https://cdn.ymaws.com/www.iodsa.co.za/resource/ collection/879CAE6C-7B90-49F5-A983-28AECBCE196F/PSWG_Position Paper_3_Governance_in_SOEs.pdf.

PriceWaterhouseCoopers. (2012). Steering Point Companies Act Series No: 4. Retrieved from https://www.pwc.co.za/en/assets/pdf/companies-act-steeringpoint-4.pdf.

PriceWaterhouseCoopers. (2015). State-owned enterprises. Catalysts for public value creation? Retrieved from https://www.pwc.com/gx/en/psrc/publications/assets/ pwc-state-owned-enterprise-psrc.pdf. 
Reddy, K., \& Wang, S. (2014). Are CEOs paid like bureaucrats? A comparative study of public sector corporations and publicly listed companies in New Zealand.
Retrieved from http://www.nzfc.ac.nz/archives/2014/papers/programme/II2c.pdf.

Rena, R., \& Msoni, M. (2014). Global financial crises and its impact on the South African economy: A further update. Journal of Economics, 5(1), 17-25. https:// doi.org/10.1080/09765239.2014.11884980

Republic of South Africa. (2008). Companies Act 71 of 2008. Pretoria: Government Printers. Retrieved from https://www.gov.za/documents/companies-act\#: :text= The $\% 20$ Companies $\% 20$ Act\%2071\%20of,on\%20business\%20within $\% 20$ the $\% 20$ Republic\%3B\&text=to\%20repeal\%20the\%20Companies\%20Act\%2C\%201973\%20 (Act\%20No.

Scholtz, H., \& Smit, A.R. (2015). Factors influencing corporate governance disclosure of companies listed on the alternative exchange (AltX) in South Africa. South African Journal of Accounting Research, 29(1), 29-50. https://doi.org/10.1080/ 10291954.2015.999471

Shaw, P. (2011). CEO pay-performance sensitivity in South African financial services companies. Masters dissertation. Pretoria: Gordon Institute of Business Science. Retrieved from https://repository.up.ac.za/bitstream/handle/2263/27027/ dissertation.pdf?sequence $=1$.

Sonenshine, R., Larson, N., \& Cauvel, M. (2016). Determinants of CEO compensation before and after the financial crisis. Modern Economy, 07(12), 1455-1477. https://doi.org/10.4236/me.2016.712133

South African Qualifications Authority. (2013). Policy on avoidance of irregular unauthorised, fruitless, and wasteful expenditure. Retrieved from http://www. saqa.org.za/docs/pol/2014/FPG $\% 2003 \% 20$ Avoidance $\% 20$ of $\% 20$ irregular $\% 20$ unauthorised, $\% 2$ fruitless $\% 20$ and $\% 20$ wasteful $\% 20$ expenditure $\% 20$ approved\%202013-12-04.pdf.

Stoddard, E. (2020, March 3). SA economy in recession after shock Q4 data, 2019 growth lowest in a decade. Daily Maverick on MSN.Com. Retrieved from https://www.msn.com/en-za/money/markets/sa-economy-in-recessionafter-shock-q4-data-2019-growth-lowest-in-a-decade/ar-

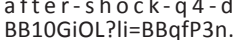

StaffWriter. (2017a, August 6). CEO vs employee salaries at South Africa's biggest companies. BusinessTech. Retrieved from https://businesstech.co.za/news/ finance/190506/average-employee-vs-ceo-salaries-at-south-africas-25-biggestcompanies/.
StaffWriter. (2017b, August 27). CEO vs employee salaries at Eskom, SAA and other state companies. BusinessTech. Retrieved from https://businesstech.co.za/news/ wealth/194164/ceo-vs-employee-salaries-at-eskom-saa-and-other-statecompanies/.

Statista. (2020). South Africa: Inflation rate from 1984 to 2021 (compared to previous years). Retrieved from https://www.statista.com/statistics/370515/inflation-ratein-south-africa/.

Steyn, G.F. (2015). The relationship between CEO compensation and future share returns in South Africa (p. 45). MCom dissertation. Cape Town: University of Western Cape. Retrieved from https://pdfs.semanticscholar.org/41e6/45afb271c f315d088a48c44a99c716a6236b.pdf.

South African Reserve Bank. (2019). Quarterly Bulletin South African Reserve Bank. Retrieved from https://www.resbank.co.za/Lists/News\%20and\%20Publications/ Retrieved from https://www.resbank.co.za/Lists/News\%20
Attachments/9632/01Full\%20Quarterly\%20Bulletin.pdf.

Tabachnick, B.G., \& Fidell, L.S. (2003). Using multivariate statistics. Boston, NY: Allyn \& Bacon.

Van Blerck, T.G. (2013). The relationship between executive remuneration at financia institutions and economic value added. Masters dissertation. Pretoria: University of Pretoria, Gordon Institute of Business Science. Retrieved from https:// repository.up.ac.za/bitstream/handle/2263/23060/dissertation.pdf;sequence=1.

Vemala, P., Nguyen, L., Nguyen, D., \& Kommasani, A. (2014). CEO compensation: Does financial crisis matter? International Business Research, 7(4), 125-131. https:// doi.org/10.5539/ibr.v7n4p125

Ward, M., \& Price, A. (2017). Turning vision into value. Johannesburg: Van Schaik Publishers.

Weiers, R.M. (2010). Introduction to business statistics (7th edn.). Mason, IA: SouthWestern Cengage Learning.

Westhoff, F. (2013). In introduction to econometrics: A self-contained approach, Cambridge, MA: Massachusetts Institute of Technology.

Williams, J.R., Haka, S.F., Bettner, M.S., \& Carcello, J.V. (2006). Financial accounting (12th edn.). New York, NY: McGraw-Hill International Edition.

Xin, Q.Q., \& Tan, W.Q. (2009). Market-oriented reform, firm performance and executive compensation in Chinese state-owned enterprises, Economic Research Journal, 11, 99-108.

Yang, F., Dolar, B., \& Mo, L. (2014). CEO compensation and firm performance: Did the 2007-2008 financial crisis matter? Journal of Accounting and Finance, 14(1), 137-146. 2007-2008 financial crisis matter? Journal of Accounting and Finance, 14(1), 137-1
Retrieved from http://www.na-businesspress.com/JAF/YangF_Web14_1_.pdf. 